\title{
The Impact of Liquidity Risk of Commercial Banks on Systematic Risk of Banking Industry: Study of 16 Listed Commercial Banks
}

\author{
Qingxia Li \\ School of Economics, Jinan University, Guangzhou, China \\ Email: lqx345643830@163.com
}

How to cite this paper: Li, Q.X. (2019) The Impact of Liquidity Risk of Commercial Banks on Systematic Risk of Banking Industry: Study of 16 Listed Commercial Banks. Modern Economy, 10, 645-665.

https://doi.org/10.4236/me.2019.103044

Received: February 14, 2019

Accepted: March 9, 2019

Published: March 12, 2019

Copyright $\odot 2019$ by author(s) and Scientific Research Publishing Inc. This work is licensed under the Creative Commons Attribution International License (CC BY 4.0).

http://creativecommons.org/licenses/by/4.0/

\begin{abstract}
The US subprime mortgage crisis erupted in 2007, and the most fundamental reason was the depletion of financial intermediation liquidity. The rapid spread of liquidity crisis in the interconnected financial markets, so financial institutions took excessive risks and collapsed. Then the final liquidity risk evolved into systemic risk. Firstly, this paper studies the development history and the latest progress of systematic risk management, the theory of liquidity risk management and the theory of risk-taking behavior management. The paper constructed two dynamic Division number regression to measures $\Delta \mathrm{CoVaR}$ of 16 commercial banks. Then the dynamic panel regression model is built, which takes the liquidity risk index of individual commercial bank and the interaction between individual commercial bank liquidity risk index and risk-taking index as the main explanatory variables to analyze the banking systemic risk. The research finds that the greater the liquidity risk of individual commercial banks, the higher the contribution of their systemic risk. The risk-taking of individual commercial bank can play an effective role in regulating and weakening its $\Delta \mathrm{CoVaR}$. In addition, the large size of the bank does not mean that the greater the contribution of its systemic risk. In terms of liquidity risk regulation, banks would better use liquidity creation indicators and liquidity ratios, rather than loan-to-deposit ratios. Finally, combined with the results of empirical analysis and theoretical analysis, this paper puts forward some suggestions on bank risk management.
\end{abstract}

\section{Keywords}

Commercial Bank Risk Management, Banking Systemic Risk, Liquidity Risk, CoVaR, Dynamic Quantile Regression 


\section{Introduction}

Before the outbreak of the subprime mortgage crisis, liquidity risk management showed extensively and inefficiently. Then strengthening financial risk supervision after the financial crisis has become a general consensus of all countries. In December 2010, Basel III came into being, as a result, Liquidity regulation and capital regulation have become two important requirements of financial supervision. In view of the liquidity risk of commercial banks, in January 2013, the Basel Committee put forward two major liquidity risk monitoring indicators in the International Framework for Liquidity Risk Measurement Standards and Testing: one is the Liquidity Coverage Ratio (LCR), the other is the Net Stable Funding Ratio, which guides the banking financial institutions to strengthen the management of individual liquidity risk. In academia, researchers focus on monitoring systematic risk of banking industry. In September 2015, CBRC issued the revised "Measures for Liquidity Risk Management of Commercial Banks (Trial Implementation)", pointing out that the liquidity risk monitoring indicators include liquidity coverage and liquidity ratio, in which the liquidity coverage should not be less than $100 \%$ and the liquidity ratio should not be less than $25 \%$. However, China has not been into a systemic crisis, lacking of experience in risk management and pays insufficient attention to liquidity risk management. In recent years, the profit-seeking motivation of domestic commercial banks has become increasingly evident. The unreasonable structure of assets and liabilities, the mismatch of assets and liabilities, and the shortage of liquidity have caused liquidity risks, leading to the accumulation of systemic risks in the banking industry. The system of industrial supervision in China is still not suitable for the highly infectious and complex risks. In recent years, China's commercial banks have made great efforts in liquidity risk management, paying attention to the micro-basis of macro-prudential supervision, and further strengthening the attention to liquidity risk supervision of the banking industry. Based on this, this paper will carry out the research.

Previously scholars have made a lot of high-quality papers on the two topics: banking systemic risk and commercial bank liquidity risk, commercial bank liquidity risk and risk-taking. However, few studies only take commercial bank repayment risk as the measurement index of risk-taking, and preliminarily study the relationships between the banking systemic risk、 commercial bank liquidity risk and risk-taking. Repayment risk is an embodiment of bank risk-taking. However, there are few studies on the overall level of risk-taking, the allocation of risk assets and the ability of risk-taking of commercial banks. In addition, many literatures use risk management tools to measure the $\Delta \mathrm{CoVaR}$ of commercial banks and has not been fully applied and verified. Most of the indicators of liquidity risk management articles are for individual commercial banks. Practice shows that liquidity risk and liquidity crisis will still occur even if banks meet the liquidity regulatory indicators. Therefore, banks and regulatory authorities should not only monitor liquidity risk regulatory indicators but also com- 
bine liquidity regulatory indicators with risk-taking indicators to manage systemic risk of banks.

Firstly, this paper discusses the theory of risk management. Secondly, according to the dynamic CoVaR theory proposed by Adrian and Markus K. Brunnermeier (2011) [1], we use the quantile regression model to measure the $\Delta \mathrm{CoVaR}$ of commercial banks. In this model we introduce macroeconomic variables more in line with the characteristics of the banking market. Then a dynamic panel regression model is built to explore the impact of commercial liquidity risk and its risk-taking on the systemic risk of banking industry. The regression results show that, compared with joint-stock banks and city commercial banks, $\mathrm{VaR}$ and $\Delta \mathrm{CoVaR}$ of state-owned banks are relatively low and stable, with city commercial banks having the highest performance and the largest fluctuation range. $\mathrm{VaR}$ of commercial banks corresponds to $\triangle \mathrm{CoVaR}$ in time. The larger the $\mathrm{VaR}$ of banks is, the greater its spillover effect on systemic risk of banking industry is. During the non-crisis period, $\mathrm{VaR}$ and $\mathrm{CoVaR}$ of some banks are obviously larger than those of the other banks, which may lead to a systemic crisis of the banking industry and that's what we called "one-off and whole-body". Secondly, the more liquidity creation and the higher deposit-loan ratio of commercial banks, the greater their contribution to the systemic risk of the banking industry, and to some degree the higher the liquidity ratio of banks, the larger the proportional to its systemic risk is. Then the risk-taking of commercial banks is proportional to the contribution of systemic risk of banks, and excessive risk-taking will aggravate the banking crisis. Finally, the combination of risk-taking behavior of commercial banks and liquidity risk monitoring indicators can play a positive role in regulating and improving systemic risk. Finally, the paper puts forward some suggestions on the liquidity risk management and risk-taking management of banks, in order to achieve the role of systemic risk supervision of the banking industry.

According to the research logic of finding, analyzing and solving problems, the paper is organized as follows:

The first part is the introduction, which mainly introduces the research background and significance, research ideas, research methods and research results.

The second part is the literature review. It mainly reviews existing domestic and foreign literature from three topic: the impact of liquidity risk on banking systemic risk, the relationship between liquidity risk and risk-taking of commercial banks, and the impact of different types of banks on banking system risk. Finally, it expounds the progress and shortcomings of current research, and points out the research space of this paper.

The third part firstly analyses the commonly used systematic risk measurement methods, and then uses the dynamic CoVaR method to measure the $\Delta \mathrm{CoVaR}$ of commercial bank, and makes a comparative analysis of the measurement results.

The fourth part establishes the dynamic panel regression model. The explained variable is the $\Delta \mathrm{CoVaR}$ measured in the third part. The explanatory va- 
riable is the liquidity risk supervision index, risk-taking variable and their interaction. The control variable is divided into two parts, which are the micro-and macro-factors controlling the factors. The results were explained and analyzed in this part.

In the fifth part, according to the theoretical analysis and empirical analysis before, the basic conclusions are summarized, and the corresponding banking risk management suggestions as to the micro-foundation of the banking industry are given, in order to promote the prevention and management of Banking Systemic risk.

\section{Literature Review}

In the research of international financial, the research on systemic risk of banking industry is not very mature, and there is no complete theoretical system. At present, there is no uniform definition of systemic risk of banking industry in the world, which shows the complexity of systemic risk of banking industry itself. Bandt and Hartmann (2000) [2] have studied the definition of systemic risk. In a narrow sense. They describe the bankruptcy or crisis of a financial institution or financial market will cause the crisis of other individuals or financial markets and even other markets to a large extent. Broadly speaking, they also include the possibility that the sudden impact of the systemic risk will cause crisis to many other financial institutions or even markets. Berger and Bouwman (2009) [3] analyze all US banks from 1993 to 2003. They divided their balance sheet activities and off-balance-sheet activities into three categories: liquidity, semi-liquidity and illiquidity. They give different weights, and then calculated the liquidity creation of banks. The results show that the liquidity creation of banks is increasing every year, while the liquidity creation of newly established banks is greater. Although the liquidity risk of commercial banks directly leads to bankruptcy, it is a comprehensive risk, which is caused by the long-term underline, accumulation and transformation of other risks. Therefore, in order to control the liquidity risk of commercial banks, we must first discover and control other types of risks of commercial banks. Jensen and Meckling (1976) [4] first put forward the concept of risk-taking in the principal-agent problem discussed in the 1970s. In a narrow sense, it refers to the internal risk-taking behavior of banks. The most direct and active risk-taking behavior is a dynamic process. Another kind of external behavior refers to the systematic risk-taking behavior of the banking industry. The interaction of the main bodies of commercial banks in the risk-taking behavior has an impact on other banking institutions or other industries in the financial system, and even on the real economy. Whether commercial banks are willing to take risks and whether they can manage risks properly will determine their profit and loss. Although the risktaking of banks is the reason for the existence and development of banks, if banks take excessive risks, they will eventually pay a huge price for themselves. Serious bank crises will erupt. Because of the huge negative external effects of banks, bank crises will impact the real economy. 


\subsection{Research on the Relationship between Liquidity Risk and Systematic Risk of Banking Industry}

Foreign research on liquidity risk and stability of banking system can be traced back to Diamond and Dybvig (1983) [5], classical DD model. The DD model mainly studies the relationship between systemic liquidity risk and bank runs. Drehmann and Nikolaou (2008) [6] also pointed out that financing liquidity risk is stable for most of the time, but it happen accidentally. The interaction between financing and market liquidity can lead to a vicious circle, which will lead to a significant increase in market liquidity risk. Adrian and Brunnermeier (2011)] [1] studied the relationship between liquidity risk of commercial banks and Co$\mathrm{VaR}$ of banking industry from the perspective of short-term debt financing of financial institutions. It was found that the higher the short-term debt ratio of banks, the greater the liquidity risk they faced, and the greater the possibility of systemic risk of banking industry. When Qiang Sun and GuanghuaCui (2017) [7] measure the risk of the banking system, they conclude that credit risk and liquidity risk are the main fuses of the systemic risk of the banking industry in China.

From the empirical analysis of China's commercial banks, banks will increase the reserve liquidity assets to cope with the risk in the period of increasing financial risk. Generally speaking, the higher the liquidity ratio, the smaller the liquidity risk, and the more stable the banking system should be. However, Wagner (2005) [8] studies liquidity risk in crisis and non-crisis periods show that the increase of liquidity assets in crisis period will increase the risk of the banking system and reduce the stability of the financial system, while the increase of liquidity assets ratio in normal period of the financial system will increase the risk of banks, but has no impact on the stability of the financial system.

\subsection{Research on Liquidity Risk and Risk-Taking of Commercial Banks}

There are relatively few papers directly studying the liquidity risk and risk-taking of commercial banks. The best explanation comes from Diamond and Rajan (2001) [9]. They point out that the term mismatch between short-term deposits and non-liquidity loan leads to the fragile confidence of banks to depositors. If there is a large amount of deposit outflow, banks hold liquidity non-performing loans which are difficult to sell in a short time and will incur losses, leading to liquidity risk and increasing bank risk-taking; Vazquez and Federico (2015) [10] use data from 2001 to 2009 of American and European commercial banks to conclude that before the crisis, liquidity risk aggravates the risk-taking of commercial banks, and banks are more likely to do so. It can go bankrupt. Since the 2008 crisis, domestic scholars have also strengthened their research on liquidity risk. Shusong Ba, Ping Yuan, Huiyu Li, et al. (2007) [11] proposed that the declining asset quality, the inadequate maturity ratio of assets, and the deteriorating commercial reputation, make commercial banks take excessive risks, unable 
to effectively raise funds from financial markets, and inaccurately estimates the time and amount of cash withdrawal from customers. Secondly, some commercial banks do not pay enough attention to asset management. The small size of their own capital pool will also reduce the ability of commercial banks to resist liquidity risk and increase their risk-taking. JunxunDai and Chunxi Tao (2016) [12] point out that the liquidity coverage and net stable capital ratio under the macro-prudential framework will limit the liquidity allocation of banks and at the same time encourage banks to stay away from low liquidity assets in order to maintain short-term liquidity standards, and reduce liquidity risk. The adjustment of bank risk-taking behavior is mainly based on risk preference channel, which emphasizes the liquidity risk of assets.

\subsection{Research on the Impact of Different Types of Banks on Systematic Risk of Banking Industry}

Shengfu Liu and Cheng Li (2014) [13] studied the risk taking of systemically important commercial banks. It is pointed out that banks with higher self-capital ratio will not radically expand risk-taking, but can cushion the impact on non-performing loans and be more robust in the face of shocks. Weixing Wu et al. (2016) [14] uses the method of Covar to analyze the interbank deposit in current liabilities of Chinese commercial banks, and finds that different banks have different liquidity risk contagion characteristics, small commercial banks may initiate through the expansion of systemically important banks and lead to Banking Systemic risk. Xiaoling Wu (2010) [15] pointed out that the probability of crisis in large financial institutions is less than that in small financial institutions, but once it happens, the negative impact is much greater than that of small institutions. However, the "big but not fail" policy is a destructive behavior in the financial field. ZhiyangLiu (2017) [16] pointed out that China's banking industry is different from the European and American banking industry. The increase of bank size does not mean the increase of bank risk. The $\Delta \mathrm{CoVaR}$ of large commercial banks is not necessarily high. Therefore, we can not only consider the scale factor to study the reasons for the increase of systemic risk in China's commercial banks. The empirical analysis shows that liquidity risk between listed commercial banks in China has a positive impact on each other. However, the large state-owned commercial banks have negative influence on each other, and there is an automatic stabilization mechanism of liquidity risk. The large state-owned commercial banks and joint-stock commercial banks can automatically adjust their operating strategies according to the overall liquidity risk of the same industry to reduce the risk of banking failure, thereby reducing the impact on the systemic risk of the banking industry.

Tianyu Yang and Yuping Zhong (2013) [17] hold different opinions. Given that other variables remain unchanged, the increase of bank assets will lead to the increase of bank risk. This shows that domestic banks also have the phenomenon of "too big to fail". The larger the bank assets, the more vulnerable they are to the protection of implicit government policies. But it also points out that 
the high-risk financial products of big banks may be more than those of small banks, and the potential risks are greater. In the process of banking practical supervision, once the banks of the same country get into the event of a crisis, the same central bank is expected to act as the lender of last resort. But even in the same country, the difference size of bank will lead to result that during the financial crisis the probability of large banks with systemic importance may be rescued while those small and medium-sized banks may be not. In terms of prior supervision, Weidong Guo (2013) [18] proposed that the regulatory authorities should divide financial institutions into different levels according to the difference of systematic importance, and adopt different regulatory policies for different levels of financial institutions according to the practice. Commercial bank risks have an impact on the systemic risk of banking industry through contagion and spread. This transmission varies with its risk-taking. Commercial banks have different risk-taking behaviors when facing liquidity risk, so the impact on systemic risk of banking industry is also various.

\subsection{Dynamic CoVaR Measures Systemic Risk}

In July 1993, the Research Report “Time and Rules of Derivatives" issued by the Group of 30 firstly use the term of VaR risk value, introducing VaR as a risk management tool into the practice of asset assessment and financial risk assessment. In April 1995, the Basel Committee launched an extension of the market risk model, allowing banks to use their own VaR model to determine their capital requirements. Then $\mathrm{VaR}$ was recognized by more and more institutions, and VaR theory gradually developed into a mainstream risk management tool.

$\mathrm{VaR}$ represents the maximum possible loss of a portfolio in a given confidence interval. The mathematical formulas are expressed as follows: $\operatorname{Prob}(\Delta P \leq-\mathrm{VaR})$ $=1-C$.

Prob is a probability measure, $\Delta P=P(t+\Delta t)-P(t)$ represents the loss of the portfolio in the subsequent holding period $\Delta t, P(t)$ represents the value of the portfolio at the current time $t$ (or yield), $C$ is the level of confidence, and $\mathrm{VaR}$ is value when the portfolio is at risk at the level of confidence $C$. For example, the probability of that the loss is not exceeding 1 million yuan in the next day (holding period) is $90 \%$. This can be expressed as: $\operatorname{Prob}(\triangle P \leq-1$ million $)=10 \%$. If portfolio returns are regarded as a random variable, $\mathrm{VaR}$ can be regarded as a quantile of the distribution of revenue.

Assuming that the revenue_is a continuous random variable and the probability density function is $f(\cdot)$, the $\mathrm{VaR}$ of the portfolio revenue is the lower $1-\alpha$ quantile of the distribution, that is:

$$
\int_{-\infty}^{-\mathrm{VaR}} f(t) \mathrm{d} t=1-\alpha
$$

If the revenue_follows a discrete distribution, $\mathrm{VaR}$ can be obtained by the following formula: $\sum_{r<-\mathrm{vaR}} \operatorname{prob}(r)=1-\alpha$

In August 2007, both academia and practice found the limitations of VaRmade it difficult to measure the bank's risk. Based on this, Adian and Brunner- 
meier firstly proposed CoVaR (conditional value at risk) method in their 2008 report on the work of the Federal Reserve Bank of New York. This method of risk measurement, based on $\mathrm{VaR}$, can really add conditional probability to the spillover effect analysis of financial risk. It reflects the contribution of individual institutions to the systemic risk of the banking industry or of the whole system.

$\mathrm{CoVaR}_{q}^{j \mid i}$ represents that at the confidence level of 1- $q$ financial institution $\mathrm{i}$ is in extreme situation when the return of institution $i$ is $\operatorname{VaR}_{q}^{i}$, the most likely loss of the asset portfolio of institution $j$ In generally speaking, Which can be expressed as follows: $\operatorname{Prob}\left(X_{q}^{i} \leq \operatorname{CoVaR}_{q}^{j \mid i} \mid X_{q}^{i}=\operatorname{VaR}_{q}^{i}\right)=q$.

The contribution of financial institution $i$ to risk spillover or the concept of analysis to financial institution $j \Delta \mathrm{CoVaR}_{q}^{j \mid i}$ is defined as: at a certain confidence, the maximum loss of financial instituition $j$ is equal to the difference between $\operatorname{CoVaR}_{q}^{j \mid X_{q}^{i}=\operatorname{VaR}_{q}^{i}}$ when instituition a $i$ is at its maximum loss $\operatorname{VaR}_{q}^{i}$ and $\mathrm{CoVaR}_{q}^{j \mid X_{q}^{i}=\operatorname{VaR}_{q}^{i}}$ when $i$ is at median loss

$$
\begin{gathered}
\left(\operatorname{Prob}\left(X_{q}^{i} \leq \operatorname{CoVaR}_{q}^{j \mid i} \mid X_{q}^{i}=\operatorname{VaR}_{q}^{i}\right)=50 \%\right) \\
\Delta \operatorname{CoVaR}_{q}^{j \mid i}=\operatorname{CoVaR}_{q}^{j \mid X_{q}^{i}=\operatorname{VaR}_{q}^{i}}-\operatorname{CoVaR}_{0.5}^{j \mid X_{q i}^{i}=\operatorname{median}_{q, i}^{i}}
\end{gathered}
$$

When we regard $j$ as the bank system, $\Delta \mathrm{CoVaR}_{q}^{j \mid i}$ correspondingly become the risks pillovers of individual commercial banks to the whole banking system or their contribution value to the systemic risk of banking industry.

In order to capture the time-varying of marginal risk of individual institutions, Adrian and Brunnermeier (2011) [1] developed a dynamic CoVaR model by introducing state variables of lag period, and the dynamic CoVaR model consists of two regression equations. Individual commercial banks need to estimate and measure two conditional VaR:

$$
\begin{gathered}
X_{t}^{i}=\alpha_{q}^{i}+r_{q}^{i} M_{t-1}+\varepsilon_{q, t}^{i} \\
x_{q, t}^{\text {system } \mid i}=\alpha_{q}^{\text {system } \mid i}+\beta_{q}^{\text {system } \mid i} x_{t}^{i}+r_{q, t}^{\text {system } \mid i} M_{t-1}+\varepsilon_{q, t}^{\text {system } \mid i}
\end{gathered}
$$

The dependent variable $x_{t}^{i}$ in Equation (1.1) is measured by the weekly return of stocks. $M_{t-1}$ controls the change of asset market value, which is a state variable lagging first order. For (1.1) quantile regression ( $q$ for quantile), the parameter estimates of the two equations $\hat{a}_{q}^{i}$ and $\hat{r}_{q}^{i}$, can be obtained first. The value at risk $\operatorname{VaR}(q)$ of instituition $i$ at t time can be obtained.

$$
\operatorname{VaR}_{q, t}^{i}=\hat{a}_{q}^{i}+\hat{r}_{q}^{i} M_{t-1}
$$

Then, the $X_{t}^{i}=\mathrm{VaR}_{q, t}^{i}$ and the weekly return rate of bank index are substituted into Equation (1.4) for regression, and the parameter estimate $\hat{\alpha}_{q}^{\text {system|i }}$, $\hat{\beta}_{q}^{\text {system } \mid i}$ and $\hat{r}_{q}^{\text {system } \mid \mathrm{i}}$ are obtained through the Equation (1.4).

$$
\mathrm{CoVaR}_{q, t}^{i}=\hat{\alpha}_{q}^{\text {system } \mid i}+\hat{\beta}_{q}^{\text {system } \mid i} \mathrm{VaR}_{q, t}^{i}+\hat{r}_{q}^{\text {system } \mid \mathrm{i}} M_{t-1}
$$

Through the calculation to Equation (1.4) we can obtain the $\operatorname{CoVaR}_{q, t}^{i}$ of banks:

$$
\Delta \operatorname{CoVaR}_{q, t}^{i}=\operatorname{CoVaR}_{q, t}^{i}-\operatorname{CoVaR}_{0.5, t}^{i}=\hat{\beta}_{q}^{\text {system } \mid i}\left(\operatorname{VaR}_{q, t}^{i}-\operatorname{VaR}_{0.5, t}^{i}\right)
$$


There are $16 \mathrm{~A}$-share listed banks in the sample, which account for $95.99 \%$ of the market value of A-share commercial banks in China. They also include state-owned banks, joint-stock banks and city commercial banks, which can better represent the various components of the banking system. The bank index is expressed by the wind secondary market banking index. The data in this paper are all from the Wind consulting terminal.

The listing time of CIB is August 20, 2010. Considering the listing time and research time span of the 16 listed banks mentioned above, the starting date for calculating the bank's overall index and stock returns is August 20, 2010-June 30,2018 . The stock price adopts the pre-reinstatement method, with a total of 404 observations.

The criteria for selecting state variables are related to the rate of return on assets, the difficulty of financing and the market interest rate. So we choose the three-month treasury bond yield (V1). The term spread (V2) reflects the difference between 10-year Treasury Bond Yield-1-year Treasury Bond Yield. And the Weekly Return Rate of Shanghai and Shenzhen 300 Index stands for Weekly Return Rate of Market. Because the influence of state variables on the revenue is time-lagged, these state variables are treated with lag first order. The explanation of dynamic CoVaR model state variables are listed in Table 1 and the descriptive statistics of state variables can be found in Table 2 .

The one order difference of the weekly closing price of each bank's stock is used to calculate the index of the bank sector and the weekly return of each bank's stock. The formula is as:

$$
R_{t}=\ln \frac{P_{t}}{P_{t-1}}
$$

It shows that the data peaks and thick tails of state variables refuse to obey the hypothesis of normal distribution and satisfy the conditions of using quantile regression model. According to $\mathrm{ADF}$ test, each sequence rejects the original

Table 1. Explanation of dynamic CoVaR model state variables.

\begin{tabular}{|c|c|c|}
\hline Variable & Variable symbol & Variable description \\
\hline Three-month Treasury Bond Yield Rate & $\mathrm{V} 1$ & Recent bank earnings \\
\hline Weekly Return Rate of Shanghai and Shenzhen 300 Index & V3 & Weekly Return Rate of Market \\
\hline
\end{tabular}

Table 2. Descriptive statistics of state variables.

\begin{tabular}{cccccccccccc}
\hline $\begin{array}{c}\text { Discription } \\
\text { Variables }\end{array}$ & Mean & median & maximum & minimum & $\begin{array}{c}\text { Standard } \\
\text { deviation }\end{array}$ & skewness & kurtosis & JB value & probability & observations \\
\hline V1 & 0.16 & -0.02 & 50.10 & -22.84 & 5.34 & 2.33 & 25.81 & 9127.34 & 0 & 404 \\
V2 & 0.64 & 0.59 & 1.94 & -0.03 & 0.35 & 1.01 & 4.36 & 100.19 & 0 & 404 \\
V3 & 0.02 & 0.02 & 0.03 & 0.01 & 0.003 & 3.59 & 24.46 & 8622.75 & 0 & 404 \\
\hline
\end{tabular}


hypothesis, so it can be judged that the sequence of state variables meets the stationarity requirement.

\subsection{Dynamic CoVaR Regression Analysis}

According to the above model settings and descriptive statistics of related data, we choose $q$ as 0.05 and 0.5 respectively during quantile regression. Then it come out he $\operatorname{VaR}_{q, t}^{i}$ and $\Delta \mathrm{CoVaR}_{q, t}^{i}$. According to the processing method of Liu Zhiyang's article published in Southern Finance, the average value is taken every half year as the representative of CoVaR banking industry of commercial banks in that half year. So we get the results of $\mathrm{VaR}$ and $\Delta \mathrm{CoVaR}$ are as Table 3 and Table 4 shows.

As we can see the Table 5, Ningbo Bank ranks first. In the top five banks, there are and two joint-stock banks, two state-owned banks and one city commercial bank, while Everbright Bank, Nanjing Bank, Ping An Bank, CITIC Bank and Pudong Development Bank are all in the front of ICBC and Construction Bank. Therefore, we should pay more attention to the risk management of city commercial banks and joint-stock banks, especially liquidity risk management, so as to avoid excessive impact on the systemic risk of banking industry.

From the analysis of Figure 1 and Figure 2, from the time series, the trend of $\mathrm{VaR}$ and $\Delta \mathrm{CoVaR}$ of 16 banks is basically consistent with the trend of macroeconomic changes as a whole. From the cross-sectional data, it can be concluded

Table 3. Semi-annual $\Delta$ CoVaR (0.05) of sixteen banks.

\begin{tabular}{|c|c|c|c|c|c|c|c|c|c|c|c|c|c|c|c|c|}
\hline B & $2010 \mathrm{~h} 2$ & 2011h1 & $2011 \mathrm{~h} 2$ & 2012h1 & $2012 \mathrm{~h} 2$ & 2013h1 & 2013h2 & $2014 \mathrm{~h} 1$ & $2014 \mathrm{~h} 2$ & 2015h1 & $2015 \mathrm{~h} 2$ & 2016h1 & $2016 \mathrm{~h} 2$ & 2017h1 & $2017 \mathrm{~h} 2$ & 2018h1 \\
\hline payh & -4.06 & -3.60 & -3.25 & -3.40 & -3.53 & -3.49 & -3.33 & -3.56 & -3.36 & -3.44 & -3.66 & -3.40 & -3.43 & -3.36 & -3.23 & -3.36 \\
\hline pfyh & -3.48 & -3.36 & -3.26 & -3.40 & -3.30 & -3.22 & -3.05 & -3.40 & -3.04 & -3.32 & -3.26 & -3.21 & -3.14 & -2.97 & -2.93 & -3.10 \\
\hline hxyh & -5.11 & -4.27 & -3.44 & -4.00 & -3.92 & -3.92 & -3.19 & -4.45 & -3.31 & -4.18 & -4.26 & -3.66 & -3.53 & -3.16 & -2.75 & -3.53 \\
\hline msyh & -3.51 & -3.08 & -2.70 & -2.89 & -2.96 & -2.96 & -2.72 & -3.10 & -2.77 & -2.98 & -3.13 & -2.84 & -2.84 & -2.75 & -2.58 & -2.82 \\
\hline zsyh & -4.16 & -3.79 & -3.36 & -3.69 & -3.57 & -3.41 & -3.17 & -3.96 & -3.25 & -3.83 & -3.78 & -3.46 & -3.35 & -3.14 & -2.90 & -3.41 \\
\hline xyyh & -3.65 & -3.21 & -2.78 & -3.06 & -3.03 & -2.91 & -2.67 & -3.29 & -2.71 & -3.14 & -3.20 & -2.89 & -2.83 & -2.64 & -2.44 & -2.80 \\
\hline nyyh & -4.91 & -4.29 & -3.62 & -4.06 & -3.98 & -3.98 & -3.47 & -4.47 & -3.58 & -4.26 & -4.32 & -3.82 & -3.71 & -3.46 & -3.11 & -3.78 \\
\hline jtyh & -4.33 & -3.46 & -2.66 & -3.18 & -3.16 & -3.16 & -2.43 & -3.55 & -2.52 & -3.28 & -3.42 & -2.87 & -2.76 & -2.39 & -2.04 & -2.68 \\
\hline gsyh & -4.68 & -3.68 & -2.75 & -3.31 & -3.34 & -3.34 & -2.62 & -3.79 & -2.74 & -3.49 & -3.72 & -3.04 & -2.96 & -2.62 & -2.19 & -2.91 \\
\hline gdyh & -5.33 & -4.18 & -3.11 & -3.84 & -3.75 & -3.42 & -2.73 & -4.35 & -2.86 & -3.99 & -4.08 & -3.41 & -3.18 & -2.65 & -2.16 & -3.11 \\
\hline jsyh & -4.80 & -3.99 & -3.14 & -3.68 & -3.64 & -3.40 & -2.96 & -4.16 & -3.08 & -3.88 & -4.02 & -3.39 & -3.28 & -2.95 & -2.53 & -3.29 \\
\hline zgyh & -5.07 & -4.30 & -3.42 & -4.06 & -3.85 & -3.55 & -3.08 & -4.56 & -3.24 & -4.33 & -4.29 & -3.64 & -3.44 & -3.05 & -2.57 & -3.56 \\
\hline zxyh & -4.34 & -3.66 & -2.98 & -3.44 & -3.37 & -3.37 & -2.78 & -3.80 & -2.87 & -3.58 & -3.65 & -3.16 & -3.05 & -2.75 & -2.42 & -3.05 \\
\hline nbyh & -5.24 & -4.40 & -3.63 & -4.10 & -4.12 & -4.12 & -3.49 & -4.49 & -3.59 & -4.24 & -4.42 & -3.86 & -3.78 & -3.48 & -3.13 & -3.74 \\
\hline njyh & -5.09 & -4.06 & -3.08 & -3.71 & -3.67 & -3.67 & -2.83 & -4.22 & -2.96 & -3.90 & -4.06 & -3.35 & -3.22 & -2.80 & -2.34 & -3.18 \\
\hline bjyh & -4.48 & -3.80 & -3.14 & -3.62 & -3.52 & -3.29 & -2.85 & -3.94 & -2.94 & -3.72 & -3.85 & -3.30 & -3.14 & -2.79 & -2.48 & -3.12 \\
\hline
\end{tabular}


Table 4. Semi-annual VaR (0.05) of sixteen banks.

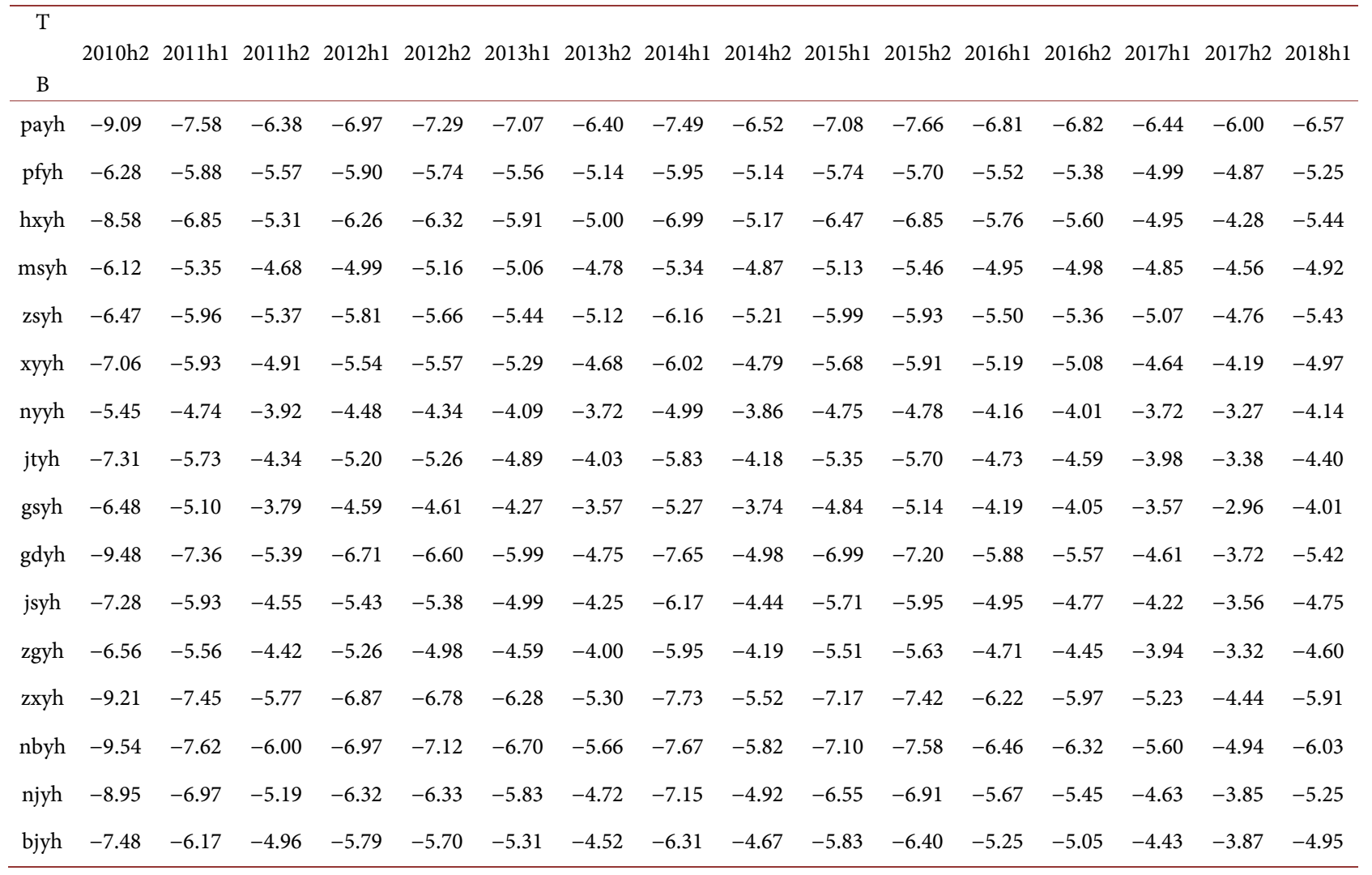

Table 5. Descriptive statistics of $\Delta \mathrm{CoVaR}$ (0.05) (in descending order of mean).

\begin{tabular}{|c|c|c|c|c|c|c|c|c|}
\hline & Mean & Median & Maximum & Minimum & Std. Dev. & Skewness & Kurtosis & Jarque-Bera \\
\hline NB & -3.99 & -3.98 & -3.13 & -5.24 & 0.51 & -0.63 & 3.41 & \\
\hline NY & -3.93 & -3.9 & -3.11 & -4.91 & 0.45 & -0.33 & 2.77 & 0.32 \\
\hline HX & -3.79 & -3.79 & -2.75 & -5.11 & 0.59 & -0.36 & 2.88 & 0.35 \\
\hline ZG & -3.75 & -3.6 & -2.57 & -5.07 & 0.65 & -0.21 & 2.49 & 0.29 \\
\hline ZS & -3.51 & -3.44 & -2.9 & -4.16 & 0.33 & -0.15 & 2.37 & 0.33 \\
\hline GD & -3.51 & -3.41 & -2.16 & -5.33 & 0.78 & -0.46 & 3.05 & 0.57 \\
\hline JS & -3.51 & -3.39 & -2.53 & -4.8 & 0.56 & -0.48 & 2.96 & 0.61 \\
\hline $\mathrm{NJ}$ & -3.51 & -3.51 & -2.34 & -5.09 & 0.68 & -0.47 & 3.09 & 0.59 \\
\hline PA & -3.47 & -3.41 & -3.23 & -4.06 & 0.2 & -1.68 & 6.09 & 13.91 \\
\hline BJ & -3.37 & -3.29 & -2.48 & -4.48 & 0.51 & -0.31 & 2.66 & 0.33 \\
\hline $\mathrm{ZX}$ & -3.27 & -3.27 & -2.42 & -4.34 & 0.48 & -0.35 & 2.87 & 0.34 \\
\hline $\mathrm{PF}$ & -3.21 & -3.24 & -2.93 & -3.48 & 0.16 & 0.22 & 1.99 & 0.8 \\
\hline GS & -3.2 & -3.18 & -2.19 & -4.68 & 0.6 & -0.66 & 3.46 & 1.29 \\
\hline JT & -2.99 & -3.02 & -2.04 & -4.33 & 0.56 & -0.5 & 3.19 & 0.7 \\
\hline $\mathrm{XY}$ & -2.95 & -2.9 & -2.44 & -3.65 & 0.3 & -0.5 & 3.05 & 0.67 \\
\hline MS & -2.92 & -2.87 & -2.58 & -3.51 & 0.22 & -1.04 & 4.27 & 3.94 \\
\hline
\end{tabular}




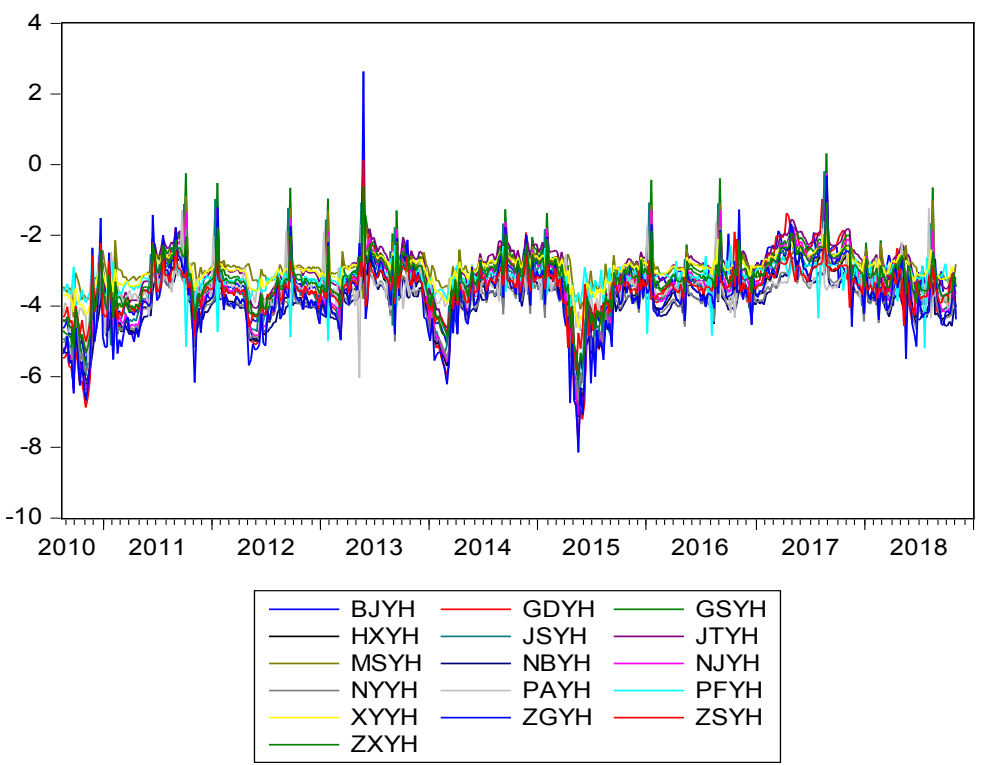

Figure 1. Time series chart of $\Delta \mathrm{CoVaR}$ of 16 Banks $(08,2010-12,2010)$ (Total).

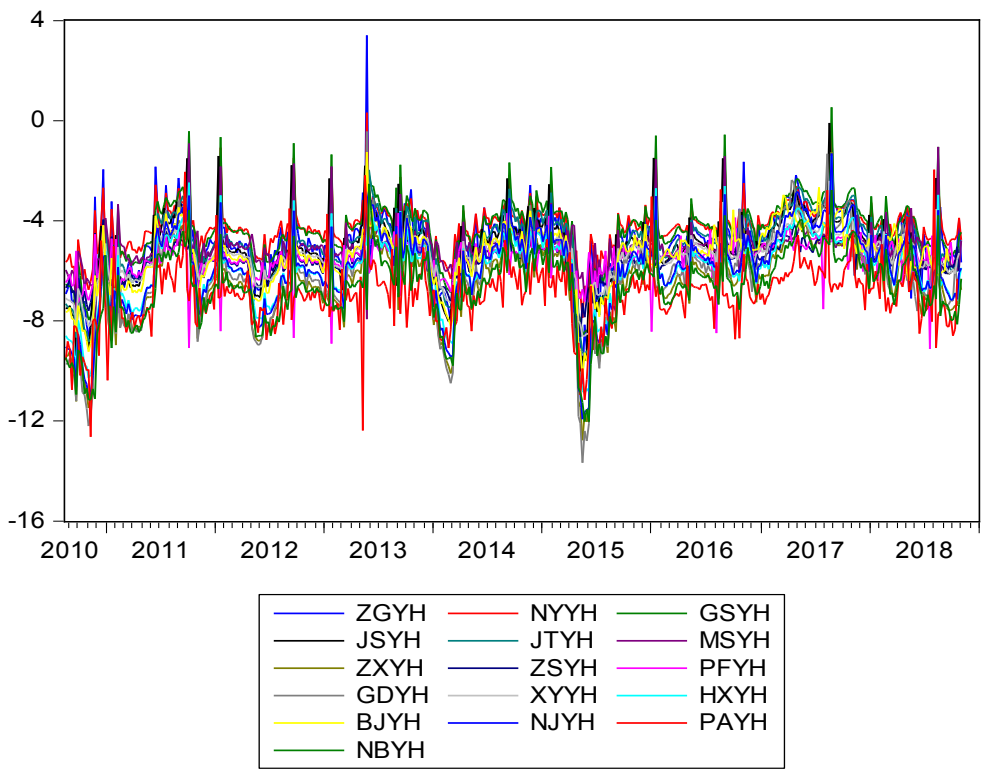

Figure 2. Time series chart of $\operatorname{VaR}(0.05)$ of 16 Banks (08, 2010-12, 2010) (Total).

that $\mathrm{VaR}$ and $\triangle \mathrm{CoVaR}$ of state-owned banks, joint-stock banks and city commercial banks are all affected by the macroeconomic situation, and are consistent with the time nodes of stock market events. As we can see from Table 6, In the 16 semi-annual data, 14 semi-annual $\Delta \mathrm{CoVaR}$ of city commercial banks are larger than that of state-owned banks, while $\Delta \mathrm{CoVaR}$ of joint-stock banks is larger than that of state-owned banks in all 16 semi-annual, which is consistent with Zhiyang Liu's research (2015). As the increase of bank risk, the $\Delta \mathrm{CoVaR}$ of large commercial banks is not necessarily high. During the period of relatively stable economic form, the risk value of joint-stock banks is larger than that of state-owned banks for a long time. Therefore, it can be concluded that the risks 
Table 6. Comparison of three types of banks (mean).

\begin{tabular}{|c|c|c|c|c|c|c|}
\hline & \multicolumn{3}{|c|}{$\mathrm{VaR}$} & \multicolumn{3}{|c|}{ CoVaR } \\
\hline & $\begin{array}{c}\text { State-owned } \\
\text { Bank }\end{array}$ & $\begin{array}{c}\text { Joint-stock } \\
\text { Bank }\end{array}$ & $\begin{array}{c}\text { City } \\
\text { Commercial } \\
\text { Bank }\end{array}$ & $\begin{array}{c}\text { State-owned } \\
\text { Bank }\end{array}$ & $\begin{array}{c}\text { Joint-stock } \\
\text { Bank }\end{array}$ & $\begin{array}{c}\text { City } \\
\text { Commercial } \\
\text { Bank }\end{array}$ \\
\hline $2010 \mathrm{~h} 2$ & -6.62 & -7.79 & -8.65 & -4.76 & -4.20 & -4.94 \\
\hline $2011 \mathrm{~h} 1$ & -5.41 & -6.54 & -6.92 & -3.94 & -3.64 & -4.09 \\
\hline $2011 \mathrm{~h} 2$ & -4.20 & -5.42 & -5.39 & -3.12 & -3.11 & -3.28 \\
\hline $2012 \mathrm{~h} 1$ & -4.99 & -6.13 & -6.36 & -3.66 & -3.47 & -3.81 \\
\hline $2012 \mathrm{~h} 2$ & -4.91 & -6.14 & -6.38 & -3.60 & -3.43 & -3.77 \\
\hline $2013 \mathrm{~h} 1$ & -4.56 & -5.83 & -5.95 & -3.49 & -3.34 & -3.69 \\
\hline $2013 \mathrm{~h} 2$ & -3.91 & -5.14 & -4.97 & -2.91 & -2.95 & -3.06 \\
\hline $2014 \mathrm{~h} 1$ & -5.64 & -6.67 & -7.04 & -4.10 & -3.74 & -4.22 \\
\hline $2014 \mathrm{~h} 2$ & -4.08 & -5.27 & -5.13 & -3.03 & -3.02 & -3.16 \\
\hline 2015h1 & -5.23 & -6.28 & -6.49 & -3.85 & -3.56 & -3.95 \\
\hline $2015 \mathrm{~h} 2$ & -5.44 & -6.52 & -6.96 & -3.95 & -3.63 & -4.11 \\
\hline 2016h1 & -4.55 & -5.73 & -5.79 & -3.35 & -3.26 & -3.50 \\
\hline $2016 \mathrm{~h} 2$ & -4.38 & -5.60 & -5.60 & -3.23 & -3.17 & -3.38 \\
\hline 2017h1 & -3.88 & -5.10 & -4.89 & -2.89 & -2.93 & -3.02 \\
\hline $2017 \mathrm{~h} 2$ & -3.30 & -4.60 & -4.22 & -2.49 & -2.68 & -2.65 \\
\hline 2018h1 & -4.38 & -5.49 & -5.41 & -3.24 & -3.15 & -3.35 \\
\hline
\end{tabular}

of joint-stock banks and city commercial banks cannot be ignored, no matter in the period of economic tension or economic stability, because once VaR of such banks may bring great impact and damage to the whole banking system. It even led to economic collapse.

\subsection{Summary of This Chapter}

One of the most important risks of commercial banks is liquidity risk. In addition, different commercial banks have great differences in liquidity risk level and risk-taking ability. How much impact liquidity risk will have on the systemic risk of banking industry? The level of risk-taking of banks will play a role in aggravating and deteriorating the systemic risk of banking industry, or This paper focuses on the role of cushioning and reducing the systemic risk of banking industry. According to this conjecture, we will take the banking sector CoVaR of each bank as the explanatory variable, and the interaction of individual commercial bank liquidity risk, individual commercial bank liquidity risk and risk-taking as the explanatory variable to examine the relationship among banking systemic risk, individual commercial bank liquidity risk and risk-taking.

\section{The Impact of Liquidity Risk Individual Commercial Banks on Systematic Risk of Banking Industry}

\subsection{Data Sources and Variables Selection}

This paper takes 16 banks listed on Shanghai Stock Exchange and Shenzhen 
Stock Exchange from August 20, 2010 to June 29, 2018 as the research target. Because the relevant indicators are only published in half a year, the indicators selected in this paper are all based on half a year as the sample period. In 16 half-yearly periods, 256 piece of datas were collected from 16 listed banks. The relevant data were collected from Wind database.

$I N S Y S_{t}^{i}$ is expressed as the contribution degree of systemic risk at time $t$ of bank $i$. This data is obtained by quartile regression in the chapter 3 in this paper. Because negative numbers represent losses, the smaller the negative number (the greater the absolute value) indicates that the spillover effect of bank VaR is greater. In addition, the $\Delta \mathrm{CoVaR}$ of banking sector lag two-order.

For liquidity indicators, the current international mainstream liquidity risk indicators is the liquidity creation indicators proposed by Berger and Bouwan (2009) [4]. In this paper, the proportion of liquidity creation in total assets is taken as the main assessment of liquidity risk indicators (LC). In this paper we use the LC index constructed by Zhiyang Liu (2016) [19]. The specific weight can be explained by referring to the literature. In addition, most domestic scholars regard liquidity ratio as the their substitute variable of liquidity risk indicators, because for commercial banks in China, liquidity assets are mainly acquired by interbank business, so liquidity ratio is chosen as the proxy variable of liquidity risk. Deposit-loan ratio refers to the ratio of total loans to total deposits, and $\mathrm{CDB}$ is used as the substitute of liquidity risk.

At present, there are mainly Z-score, expected default frequency (EDF), riskweighted asset ratio (RWATA) and non-performing loan rate. The risk-taking variable of individual commercial banks discussed in this paper is mainly from the two dimensions: asset allocation risk-taking and overall risk-taking consequences. The risk-weighted asset ratio (RWATAR) and $Z_{-}$score are selected as the measurement indicators. $Z_{-}$score is equal to the ratio of standard deviation of return on assets to the sum of roa and car. This index is often used to measure the overall risk-taking level of banks. The proportion of bankruptcy risk-weighted assets to total assets is measured by the bank's asset allocation. The larger the value, the more risk-oriented the asset allocation is, the higher the risk-taking level of banks is. This paper investigates the rate of change of risk-taking variables, which is the first-order difference of RWATA and is recorded as RWATAR. Multiplication with liquidity risk variables can be used as explanatory variables to examine whether risk-taking ability of banks can adjust the systemic risk of banking industry.

In order to effectively identify the impact of liquidity risk, other important variables affecting bank liquidity risk and risk-taking willingness and ability are also controlled, including looking at bank characteristics, considering the bank size, capital adequacy ratio (CAPI), roa, bank dependence on interbank market (INTER), and macroeconomic situation (real GDP growth rate, GROW). This paper is interested in the significance of the coefficient estimates of liquidity risk and liquidity risk and risk-taking interaction and the positive and negative symbols of the coefficient estimates. 


\subsection{Empirical Process and Result Analysis}

According to the research questions in this paper, the dynamic panel model is constructed as follows:

$$
\begin{aligned}
\text { INSYS }_{t}= & \alpha_{0}+\alpha_{1} \text { INSYS }_{t-1}+\alpha_{2} \text { INSYS }_{t-2}+\alpha_{3} \text { Liquidity }_{i, t-1} \\
& +\alpha_{4} \text { Liquidity } \text { FXCD }_{i, t-1}+\alpha_{5} \text { InSIZE }_{i, t-1}+\alpha_{6} \text { CAPI }_{i, t-1} \\
& +\alpha_{7} \text { ROA }_{i, t-1}+\alpha_{8} \text { INTER }_{i, t-1}+\alpha_{9} \text { GROW }_{t-1}+\varepsilon_{i t}
\end{aligned}
$$

Considering the second and first order lag of explained variables in the model, GMM estimation method is adopted in the dynamic panel model, which includes DIFF-GMM and SYS-GMM. DIFF-GMM can't estimate the coefficients of variables that do not change with time, and is prone to the problem of weak instrumental variables. If the "error" in regression is related to the regression quantity, it will further lead to the deviation problem. In contrast, the system GMM can solve the endogenous problem of the model by effectively using instrumental variables which are highly correlated with endogenous variables and independent of perturbation terms instead of endogenous variables. Therefore, this paper chooses DIFF-GMM and SYS-GMM estimation methods.

Liquidity is a measure of liquidity risk of banks, and FXCD measures the level of risk-taking of banks.

Firstly, the unit root test of each variable is done, and the results are as Table 7 shows.

According to other literatures, we found that the ADF test of ROA did not affect the regression results of the model. The ADF result of other variables pass the unit root test and belong to stationary series. They can be used for model regression. In view of the existence of lag second order and lag first order of the interpreted variables in the models, the dynamic panel model use DIFF-GMM and SYS-GMM estimation methods and the stability tests of LIQ and CDB are performed. The regression results are as Table 8 shows.

From the regression results of regression Equation (1)-(6), it can be concluded that INSYS (-1) and INSYS (-2) are significantly negative, and the systemic risk is loss, which is expressed in negative numbers. Therefore, it shows that the $\Delta \mathrm{CoVaR}$ of banking sector in the last two periods will have a positive impact on

Table 7. Unit root test results.

\begin{tabular}{ccc}
\hline & $\mathrm{T}$ & $\mathrm{P}$ \\
\hline INSYS & -11.947 & 0 \\
$\mathrm{lc}$ & -7.451 & 0.0085 \\
Z_score & -7.072 & 0.0059 \\
lnsize & -9.461 & 0 \\
capi & -6.858 & 0.002 \\
roa & -6.385 & 0.3972 \\
INTER & -7.692 & 0.0037 \\
\hline
\end{tabular}


Table 8. Dynamic panel regression results.

\begin{tabular}{|c|c|c|c|c|c|c|}
\hline \multirow{2}{*}{$\begin{array}{l}\text { Variable } \\
\text { model }\end{array}$} & \multicolumn{2}{|c|}{$\mathrm{LC}$} & \multicolumn{2}{|c|}{$\mathrm{CDB}$} & \multicolumn{2}{|c|}{ LIQ } \\
\hline & Equation (1) & Equation (2) & Equation (3) & Equation (4) & Equation (5) & Equation (6) \\
\hline $\mathrm{C}$ & $\begin{array}{c}-22.82635^{* * *} \\
(-4.85)\end{array}$ & $\begin{array}{c}-14.38182^{* * *} \\
(-4.96)\end{array}$ & $\begin{array}{c}-25.21523^{* * *} \\
(-4.37)\end{array}$ & $\begin{array}{c}-16.06409^{* * *} \\
(-6.26)\end{array}$ & $\begin{array}{c}-24.47524^{* * *} \\
(-3.51)\end{array}$ & $\begin{array}{c}-22.22454^{* * *} \\
(-7.38)\end{array}$ \\
\hline INSYS $(-1)$ & $\begin{array}{c}-0.2107288^{* * *} \\
(-7.12)\end{array}$ & $\begin{array}{c}-0.1959917^{* * *} \\
(-7.51)\end{array}$ & $\begin{array}{c}-0.2158194^{* * *} \\
(6.39)\end{array}$ & $\begin{array}{c}-0.1810966^{* * *} \\
(-12.04)\end{array}$ & $\begin{array}{c}-0.1857409^{* * *} \\
(-6.84)\end{array}$ & $\begin{array}{c}-0.2453089^{* * *} \\
(-7.950)\end{array}$ \\
\hline INSYS(-2) & $\begin{array}{c}-0.0404402^{*} \\
(-1.71)\end{array}$ & $\begin{array}{c}-0.0593252^{\star} \\
(-2.54)\end{array}$ & $\begin{array}{c}-0.0186192 \\
(-0,78)\end{array}$ & $\begin{array}{c}0.0019125 \\
(0.14)\end{array}$ & $\begin{array}{c}-0.0209786 \\
(-0.98)\end{array}$ & $\begin{array}{c}0.0165927 \\
(0.65)\end{array}$ \\
\hline INSYS $(-3)$ & & & & & & $\begin{array}{c}0.3153063^{* * *} \\
(9.71)\end{array}$ \\
\hline $\mathrm{LC}(-1)$ & $\begin{array}{c}-0.054899^{* * *} \\
(-7.15)\end{array}$ & $\begin{array}{c}-0.022911^{\star * *} \\
(-4.51)\end{array}$ & & & & \\
\hline $\mathrm{CDB}(-1)$ & & & $\begin{array}{c}-0.0303962^{*} \\
(-3.17)\end{array}$ & $\begin{array}{c}-0.000742 \\
(-0.15)\end{array}$ & & \\
\hline LIQ & & & & & $\begin{array}{c}-0.0525105^{*} \\
(-2.20)\end{array}$ & $\begin{array}{c}-0.0080967^{* *} \\
(-2.13)\end{array}$ \\
\hline Liquidity ${ }^{\star}$-score $(-1)$ & $\begin{array}{c}1.031055^{* *} \\
(2.81)\end{array}$ & & $\begin{array}{c}1.034508^{* * *} \\
(3.69)\end{array}$ & & $\begin{array}{c}1.169419^{* * *} \\
(1.8)\end{array}$ & \\
\hline Liquidity ${ }^{*}$ RWATAR $(-1)$ & & $\begin{array}{c}0.0000336^{* * *} \\
(3.61)\end{array}$ & & $\begin{array}{l}0.0000342^{* *} \\
\quad(3.07)\end{array}$ & & $\begin{array}{l}0.0000487^{* *} \\
\quad(2.66)\end{array}$ \\
\hline $\operatorname{lnSIZE}(-1)$ & $\begin{array}{c}1.273345^{*} \\
(5.09)\end{array}$ & $\begin{array}{c}0.7998074^{\star * *} \\
(4.69)\end{array}$ & $\begin{array}{c}1.296199^{* * *} \\
(3.96)\end{array}$ & $\begin{array}{c}0.7969351^{\star * *} \\
(5.34)\end{array}$ & $\begin{array}{c}1.299748^{\star * *} \\
(3.31)\end{array}$ & $\begin{array}{c}1.19192^{\star * *} \\
(7.16)\end{array}$ \\
\hline CAPI $(-1)$ & $\begin{array}{c}0.0379209 \\
(0.90)\end{array}$ & $\begin{array}{c}-0.0179791 \\
(-0.71)\end{array}$ & $\begin{array}{c}0.0688444^{*} \\
(2.01)\end{array}$ & $\begin{array}{c}0.017232 \\
(0.404)\end{array}$ & $\begin{array}{c}0.0814129 \\
(1.82)\end{array}$ & $\begin{array}{c}0.0109586 \\
(0.41)\end{array}$ \\
\hline $\mathrm{ROA}(-1)$ & $\begin{array}{c}0.1066729 \\
(-8.09)\end{array}$ & $\begin{array}{c}-0.430281^{\star * *} \\
(-9.41)\end{array}$ & $\begin{array}{c}0.1940112 \\
(1.27)\end{array}$ & $\begin{array}{c}-0.3954545^{\star * *} \\
(-7.01)\end{array}$ & $\begin{array}{c}-0.0159874 \\
(-0.08)\end{array}$ & $\begin{array}{c}-0.6617875^{\star * *} \\
(-10.90)\end{array}$ \\
\hline INTER $(-1)$ & $\begin{array}{c}-0.0652328^{\star * *} \\
(-8.09)\end{array}$ & $\begin{array}{c}-0.0435423^{\star * *} \\
(-5.81)\end{array}$ & $\begin{array}{c}-0.0692838^{\star * *} \\
(-6.87)\end{array}$ & $\begin{array}{c}-0.0476144^{* * *} \\
(-6.55)\end{array}$ & $\begin{array}{c}-0.0620968^{\star * *} \\
(-6.9)\end{array}$ & $\begin{array}{c}-0.0490743^{\star * *} \\
(-7.22)\end{array}$ \\
\hline GROW & $\begin{array}{c}0.1166747^{* *} \\
(3.17)\end{array}$ & $\begin{array}{c}0.1206452^{* * *} \\
(5.25)\end{array}$ & $\begin{array}{c}0.1114397^{\star *} \\
(2.74)\end{array}$ & $\begin{array}{c}0.1526044^{* * *} \\
(5.06)\end{array}$ & $\begin{array}{c}0.1591311^{* * *} \\
(4.02)\end{array}$ & $\begin{array}{c}04091157^{* * *} \\
(9.62)\end{array}$ \\
\hline
\end{tabular}

Notes: 1 . CDB and LIQ are respectively proxy variables of liquidity risk. 2. The t-statistic value is in parentheses below the estimation coefficient. 3. $(-1)$ denotes the lag first order of the variable, and $(-2)$ denotes the lag second order of the variable D. $4 .{ }^{* *}$ means significance at $1 \%$ level, ${ }^{* *}$ means significance at $5 \%$ level and ${ }^{*}$ means significance at $10 \%$ level.

the current period. The larger the INSYS $(-1)$ and INSYS $(-2)$, the larger the $\triangle \mathrm{CoVaR}$ of banking sector in the current period. The $\triangle \mathrm{CoVaR}$ of LC are significantly negative at the $1 \%$ level in Equation (1) and Equation (2). When banks increase liquidity for the society, the $\triangle \mathrm{CoVaR}$ of individual commercial bank banking increases (the systemic risk of banking is negative). In Equation (3), the coefficient estimates of $\mathrm{CDB}$ are significantly negative at the level of $10 \%$. This shows that the higher the deposit-loan ratio, the financing liquidity risk will bring negative impact on the stable operation of the banking system. In the 2008 International Financial crisis, the more deposits the commercial banks have, the stronger their desire to lend (Ivashina and Scharfstein, 2008 [20]). In Equation 
(5) and Equation (6), the coefficient estimates of LIQ is significantly negative at the level of $10 \%$, which indicates that sufficient liquidity of commercial banks may not be able to effectively reduce the systemic risk of banking industry. In order to effectively use excess liquidity and encourage commercial banks to overextend credit, they will lend funds to borrowers who do not meet the requirements of lending, that is, sufficient liquidity will easily lead to financial crisis (Adrian and Shin, 2010) [21]. During the outbreak of the financial crisis, the more liquid assets, the worse the stability of the banking system (Wagner, 2005) [16]. It can also be seen that dialectical understanding and in-depth study of the impact of liquidity risk on $\Delta \mathrm{CoVaR}$ of banking industry has important academic value and practical significance.

In Equation (1), Equation (3) and Equation (5), the coefficient estimates of 1C * Z-score $(-1), \mathrm{CDB}{ }^{*} \mathrm{Z}$-score $(-1)$ and LIQ ${ }^{*} \mathrm{Z}$-score $(-1)$ are significantly positive at the levels of $5 \%, 1 \%$ and $1 \%$, and the coefficient estimates are almost large. In Equation (2), Equation (4) and Equation (6), LC*RWATAR (-1), $\mathrm{CDB}^{\star} \mathrm{RWATAR}$ and $\mathrm{LIQ}^{\star} \mathrm{RWATAR}$ are significantly positive at $1 \%, 5 \%$ and $5 \%$ levels, respectively, with little difference in coefficient estimates. The coefficient estimates of the two groups of variables are significantly positive, indicating that the impact of liquidity risk faced by banks can be absorbed and eliminated by increasing risk-weighted assets and overall risk-taking level of individual commercial banks, thus reducing the $\Delta \mathrm{CoVaR}$ of banking industry. Z-score indicates the risk preference of banks. When liquidity risk occurs, the risk preference of banks will be adjusted to bear the risks brought by various market fluctuations, which will weaken the impact of individual commercial banks on the systemic risk of banking industry.

Next, the control variables selected by the regression model are analyzed. In the all six regression equations, the coefficient estimates of bank size are significantly positive. To some extent, the larger the bank size, the smaller the $\Delta \mathrm{CoVaR}$ of the banking industry. From 2001 to 2007 before the subprime mortgage crisis, the scale of China's banking industry grew rapidly, taking the road of scale development of extension. During the study period, that is, from the second half of 2010 to the first half of 2018, the growth rate of China's banking industry is on a downward trend. At present, the scale of banks has reached the scale effect that can disperse risks. In the face of liquidity risk, large-scale banks have stronger ability to disperse and absorb risks, which can effectively mitigate the impact of systemic risks in the banking industry. In terms of the impact on the level of risk-taking, the larger the size of the bank, in view of its social status and systemic important role, no matter its individual risk-taking or systemic risk-taking, are very large. For the relationship between CAPI of individual commercial banks and $\triangle \mathrm{CoVaR}$ of their banking industry, only Equation (3) is significant at $10 \%$ level, and the rest is not significant. That is to say, the higher the capital adequacy ratio of banks, the lower the contribution of banks to the systemic risk of banking industry, which leads to the uncertainty of the impact on the systemic risk of banking industry. ROA refers to how much income a bank generates 
per unit of assets, reflecting the level of operation of the bank. However, the regression results of Equation (2), Equation (4) and Equation (6) all show that the coefficient estimates are significantly negative, and there is a strong relationship between bank returns and risk level. In the six regression equations, the coefficient estimates of INTER are significantly negative at the level of $1 \%$, and are almost large. This shows that the more developed the interbank business, the higher the dependence between banks, which will make the contagion and spillover effect of liquidity risk very obvious, thus leading to greater contribution to the systemic risk of the banking industry. The GROW coefficient estimates of the six regression equations are significantly positive. When the macro-economic growth is fast, the operation of banks is good, and the $\triangle \mathrm{CoVaR}$ of individual commercial banks to the banking system is small. This conclusion conforms to the general logic.

At the same time, Arellano-Bond test and Sargan test are carried out to identify whether there is autocorrelation of perturbation term and over-recognition of tool variables in the model. In Table 9 and Table 10, the test results show that there is no autocorrelation of perturbation term in the model and tool variables are effective.

\section{Research Conclusions}

\subsection{Summary of the Measurement Results of $\Delta \mathrm{CoVaR}$}

Negative externality of liquidity risk of individual commercial banks is an important cause of systemic risk, which is mainly reflected in Risk Spillover and risk contagion caused by excessive institutional linkages. In terms of time series, the trend of $\mathrm{VaR}$ and $\Delta \mathrm{CoVaR}$ of 16 banks is basically consistent with the overall macroeconomic trend. From cross-sectional data, in 16 semi-annual data from the second half of 2010 to the first half of 2018 , the $\Delta \mathrm{CoVaR}$ of city commercial banks is bigger than that of state-owned banks in 14 semi-annual data, while the $\triangle \mathrm{CoVaR}$ of joint-stock banks is bigger than that of state-owned banks in 16

Table 9. Arellano-Bond test results.

\begin{tabular}{cccccccccccccc}
\hline Variables & \multicolumn{4}{c}{ LC } & \multicolumn{4}{c}{ CDB } & \multicolumn{4}{c}{ LIQ } \\
\hline Abtest & \multicolumn{1}{c}{ Equation (1) } & Equation (2) & Equation (3) & Equation (4) & Equation (5) & Equation (6) \\
\hline order & $\mathrm{Z}$ & $\mathrm{P}$ & $\mathrm{Z}$ & $\mathrm{P}$ & $\mathrm{Z}$ & $\mathrm{P}$ & $\mathrm{Z}$ & $\mathrm{P}$ & $\mathrm{Z}$ & $\mathrm{P}$ & $\mathrm{Z}$ & $\mathrm{P}$ \\
$\mathrm{AR}(1)$ & -3.57 & 0.0004 & -3.37 & 0.0007 & -3.61 & 0.0003 & -3.41 & 0.0007 & -3.49 & 0.0005 & -3.276 & 0.0011 \\
$\mathrm{AR}(2)$ & -1.25 & 0.2096 & -1.64 & 0.102 & -0.379 & 0.7044 & -1.64 & 0.1006 & -0.40 & 0.6895 & 0.126 & 0.90 \\
\hline
\end{tabular}

Table 10. Sargan test results.

\begin{tabular}{ccccccc}
\hline Variables & \multicolumn{2}{c}{ LC } & \multicolumn{2}{c}{ CDB } & \multicolumn{2}{c}{ LIQ } \\
\hline Sargan test & Equation (1) & Equation (2) & Equation (3) & Equation (4) & Equation (5) & Equation (6) \\
\hline chi & 13.6483 & 13.6337 & 13.3124 & 13.7312 & 13.2443 & 13.9506 \\
P (>chi) & 0.9997 & 1.0000 & 0.9998 & 1.0000 & 0.9998 & 1.0000 \\
\hline
\end{tabular}


semi-annual data. This shows that the increase of bank size does not mean the increase of bank risk, and the $\Delta \mathrm{CoVaR}$ of large commercial banks is not necessarily high. In addition, Ningbo Bank is the biggest contributor to the systemic risk of banking industry. One city commercial bank and two joint-stock banks in the top five banks, while Ever bright Bank, Nanjing Bank, Ping An Bank, CITIC Bank and Pudong Development Bank are in the front of ICBC and China Construction Bank. It can be seen that the $\triangle \mathrm{CoVaR}$ of banks is not only determined by the size. We pay more attention to the risk management of city commercial banks and joint-stock banks, especially liquidity risk management, so as to avoid excessive impact on the systemic risk of banks.

\subsection{Conclusion on the Impact of Bank Liquidity Risk on Systematic Risk}

The coefficient estimates of liquidity risk indicators LC and LIQ are significantly negative, which indicates that the risk of mismatching liquidity maturity of banks increases the level of overall operational risk, the expected loss of commercial banks will increase, and the CoVaR of individual commercial banks will increase. In view of the existing research results, sufficient liquidity of commercial banks may not be able to effectively reduce the systemic risk of the banking industry. On the one hand, when commercial banks have sufficient liquidity assets, they have enough resources to deal with liquidity shocks and reduce operational risks; on the other hand, sufficient liquidity will encourage commercial banks to overextend credit, which will aggravate the operational risks of commercial banks and threaten the stability of the banking system. It can also be seen that dialectical understanding and in-depth study of the impact of liquidity risk on commercial banks $\Delta \mathrm{CoVaR}$ has important academic value and practical significance.

\subsection{The Conclusion of the Moderating Role of Bank Risk-Taking}

As for the adjustment of systemic risk in the risk-taking adjustment of commercial banks, the coefficients of the interaction between liquidity risk and risktaking are significantly positive, which indicates that the impact of liquidity risk faced by banks can be absorbed and eliminated by increasing risk-weighted assets and overall risk-taking level of individual commercial banks, thus reducing the risk faced by individual commercial banks to banking CoVaR. Influence. $\mathrm{Z}$-score indicates the risk preference of banks. When liquidity risk occurs, the risk preference of banks will be adjusted to bear the risks brought by various market fluctuations, which will weaken the impact of individual commercial banks on the systemic risk of banking industry.

\section{Relevant Policy Suggestions}

Based on the above conclusions, we can draw the following policy implications:

First, it is necessary for regulatory authorities to adopt more scientific and 
reasonable liquidity regulatory indicators to effectively enhance liquidity risk management. The empirical results show that the actual effect of using deposit-loan ratio index to examine the relationship between liquidity risk of commercial banks and systemic risk of banking industry is poor, and may even have a negative effect. Although the regulatory authorities have abolished the index of deposit-loan ratio, it is still used by some commercial banks as a tool to assess and manage liquidity risk. The regulatory authorities should correct similar management methods of commercial banks. In addition, regulatory authorities should refine the description of liquidity risk monitoring indicators. Individual important indicators can be monitored separately, requiring major banks to report regularly, so as to fully grasp the real liquidity risk situation of commercial banks in China.

Secondly, we should strengthen the risk-taking management of commercial banks and give full play to the synergy between bank liquidity and risk-taking management. The empirical analysis shows that the organic combination of liquidity creation index and risk-taking variable, liquidity ratio index and risktaking variable can effectively reduce the systemic risk level of commercial banks. The improvement of bank liquidity level can inhibit or stimulate the risk-taking of commercial banks. If we only emphasize the target of bank liquidity risk supervision, it is likely to have a negative impact on commercial banks and stimulate their risk-taking level. Therefore, while implementing the liquidity risk supervision policy, the regulatory authorities should combine the liquidity risk supervision with the risk-taking management of individual commercial banks to ensure the risk-taking on liquidity risk in different dimensions of banks.

Thirdly, the scale of banks and their systemic importance will not lead to a higher degree of systemic risk contribution of banks. In non-crisis period, more attention should be paid to the risks of joint-stock banks and city commercial banks. Therefore, the original tendency towards systemically important banks and large-scale banks in crisis policy can be shifted to focus on the monitoring of small and medium-sized banks. Additional regulatory settings specific to each institution also need to reflect a certain regulatory gradient, rather than "too big to fail”.

\section{Conflicts of Interest}

The author declares no conflicts of interest regarding the publication of this paper.

\section{References}

[1] Adrian, T.B., et al. (2011) CoVaR. Princeton University Working Paper.

[2] Bandt, O. and Hartmann, P. (2000) Systemic Risk: A Survey European Central Bank. Working Paper.

[3] Berger, A.N. and Bouwman, C.H.S. (2012) Bank Liquidity Creation, Monetary Policy, and Financial Crises. Working Paper.

[4] Jensen, M.C. and Meckling, W.H. (1976) Theory of the Firm: Managerial Behavior, 
Agency Costs and Ownership Structure. Journal of Financial Economics, 3, 305-360. https://doi.org/10.1016/0304-405X(76)90026-X

[5] Diamond, D.W. and Dybvig, P.H. (1983) Bank Runs, Deposit Insurance, and Liquidity. Journal of Political Economy, 91, 401-419.

https://doi.org/10.1086/261155

[6] Drehmann, M. and Nikolaou, K. (2013) Funding Liquidity Risk. Definition and Measurement. Journal of Banking and Finance, 37. https://doi.org/10.1016/j.jbankfin.2012.01.002

[7] Sun, Q. and Cui, G.H. (2017) Design and Empirical Analysis of Systematic Risk Early Warning Index System for China's Banking Industry. Journal of Central University of Finance and Economics, 2.

[8] Wagner, W. (2005) The Broadening of Activities in the Financial System: Implications for Financial Stability and Regulation. Cambridge University, Mimeo.

[9] Diamond, D.R. (2005) Liquidity Shortages and Banking Crises. Journal of Finance, 60, 615-647. https://doi.org/10.1111/j.1540-6261.2005.00741.x

[10] Vazquez, F. and Federico, P. (2015) Bank Funding Structures and Risk: Evidence from the Global Financial Crisis. Journal of Banking and Finance, 61, 1-14. https://doi.org/10.1016/j.jbankfin.2015.08.023

[11] Ba, S.S., Yuan, P., Li, H.Y., et al. (2007) Summary of Research on Liquidity Risk Management of Commercial Banks. China Money Market, 10, 19-23.

[12] Dai, J.X. and Tao, C.X. (2016) Risk-Taking of Commercial Banks under Dual Constraints of Capital and Liquidity. Statistical Research, 12.

[13] Liu, S.F. and Li, C. (2014) Monetary Policy Regulation, Bank Risk Bearing and Macro-Prudential Management-Empirical Analysis Based on GMM Model of Dynamic Panel System. Nankai Economic Research.

[14] Wu, W.X., et al. (2016) Analysis of Liquidity Risk Contagion Characteristics of Chinese Commercial Banks Based on Time Series Data of Commercial Banks' Interbank Liabilities. International Business-Journal of University of Foreign Economics and Trade, 4.

[15] Wu, X.L. (2010) Treatment of the "Big but Not Fall" Problem in US Financial Regulatory Reform. China Finance.

[16] Liu, Z. (2017) Solvency Risk, Liquidity Risk and Banking System Risk of Commercial Banks. Financial Review, 6.

[17] Yang, T. and Zhong, Y. (2013) Concentration, Competitiveness and Bank Risk of China's Banking Industry. Financial Research, 1, 122-134.

[18] Guo, W. (2013) Global Financial Regulation Reform and Development Trend. Economic System Reform.

[19] Liu, Z. (2016) Commercial Bank Liquidity Risk, Credit Risk and Solvency Risk. Journal of Central South University of Finance, Economics and Law, 3.

[20] Ivashina, V. and Scharfstein, D. (2008) Bank Lending during the Financial Crisis of 2008. Journal of Financial Economics, 97, 319-338.

[21] Adrian, T. and Shin, H.S. (2008) Liquidity and Leverage. Federal Reserve Bank of New York, Staff Report No. 328. 